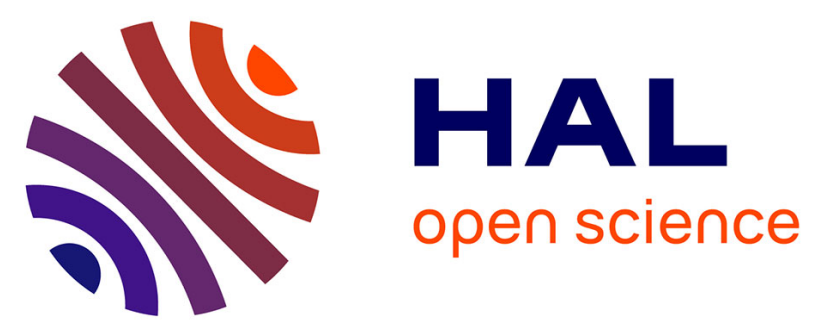

\title{
One step synthesis of D-A-D chromophores as active materials for organic solar cells by basic condensation
}

Victorien Jeux, Olivier Segut, Dora Demeter, Theodulf Rousseau, Magali Allain, Clément Dalinot, Lionel Sanguinet, Philippe Leriche, Jean Roncali

\section{- To cite this version:}

Victorien Jeux, Olivier Segut, Dora Demeter, Theodulf Rousseau, Magali Allain, et al.. One step synthesis of D-A-D chromophores as active materials for organic solar cells by basic condensation. Dyes and Pigments, 2015, 113, pp.402-408. 10.1016/j.dyepig.2014.09.012 . hal-01390934

\section{HAL Id: hal-01390934 \\ https://hal.science/hal-01390934}

Submitted on 16 Jun 2021

HAL is a multi-disciplinary open access archive for the deposit and dissemination of scientific research documents, whether they are published or not. The documents may come from teaching and research institutions in France or abroad, or from public or private research centers.
L'archive ouverte pluridisciplinaire HAL, est destinée au dépôt et à la diffusion de documents scientifiques de niveau recherche, publiés ou non, émanant des établissements d'enseignement et de recherche français ou étrangers, des laboratoires publics ou privés. 


\title{
One step synthesis of D-A-D chromophores as active materials for organic solar cells by basic condensation
}

\author{
Victorien Jeux, Olivier Segut, Dora Demeter, Théodulf Rousseau, Magali Allain, Clément Dalinot, \\ Lionel Sanguinet, Philippe Leriche*, Jean Roncali
}

MOLTECH - Anjou UMR CNRS 6200, Groupe systèmes conjugués linéaires, University of Angers, 2 boulevard Lavoisier, 49045 Angers, France

\begin{abstract}
Donor-Acceptor-Donor conjugated systems are synthesized in good yield by double condensation of aromatic aldehydes of triarylamines with 2,3-diaminomaleonitrile under microwave activation with trifluoroacetic acid as catalyst. The electronic properties of the compounds are investigated and discussed and a first evaluation of their potential as donor material in organic photovoltaic cells is presented.
\end{abstract}

\section{Introduction}

Over the past few years, many molecular conjugated chromophores combining electron donor (D) and acceptor (A) blocks have been designed and synthesized as active materials for organic solar cells (OSC) [1]. In particular solution-processable symmetrical systems D-A-D or A-D-A or even more complex structures such as D-A-D-A-D have attracted particular interest [2,3]. Intensive multidisciplinary research effort has rapidly generated impressive progresses and power conversion efficiencies (PCE) in the range of 8.0-9.0\% have been reported for solution-processed bulk heterojunction (BHJ) organic solar cells by combining extended chromophores of advanced structures with soluble derivatives of $C_{70}$ fullerene and specific additives [3].

However, such highly efficient molecules generally combine complex structure, high molecular weight and multi-step syntheses with limited overall yield. Recently several papers have discussed the key issues regarding the future industrial production of OSCs and underlined the necessity to limit the overall economic cost and environmental impact of the synthesis of

\footnotetext{
* Corresponding author. Tel.: +33241735010.

E-mail address: philippe.leriche@univ-angers.fr (P. Leriche).
}

active materials while taking care of the possibility of up-scaling the syntheses [4].

Some recent works have demonstrated the possibility of synthesizing D-A or D-A-D systems by means of more environmental friendly methods such as click chemistry [5] or basic condensations [6]. Additionally, the two-fold condensation of aromatic aldehydes onto commercial (Z)-2,3-diaminomaleonitrile to form D-A-D compounds with a central diiminofumaronitrile electro-deficient group has been scantly studied and most articles have been focused on the optical [7] or aggregative [8] properties of the compounds. A first report on the use of $N, N$-bis[4-(N,N-diethylamino)benzylidene]diaminomaleonitrile as active material in a Schottky solar cell has been published some years ago leading to a PCE of $0.38 \%$ under low intensity illumination [9].

In this context, we report here on D-A-D compounds $\mathbf{P}, \mathbf{T}$ and PT obtained by condensation of mono-formyl triarylamines with 2,3diaminomaleonitrile (Fig. 1). The optimization of the synthesis of the target compounds is presented and their electronic properties characterized by spectroscopic and electrochemical techniques with the aid of theoretical calculations are discussed in terms of structure-property relationships. If such D-A-D compounds may be useful for several kinds of applications (mainly 2 photon absorption, dyes and solar cells), we first focused on the evaluation of their potentialities as donor material in basic planar heterojunction solar cells. 


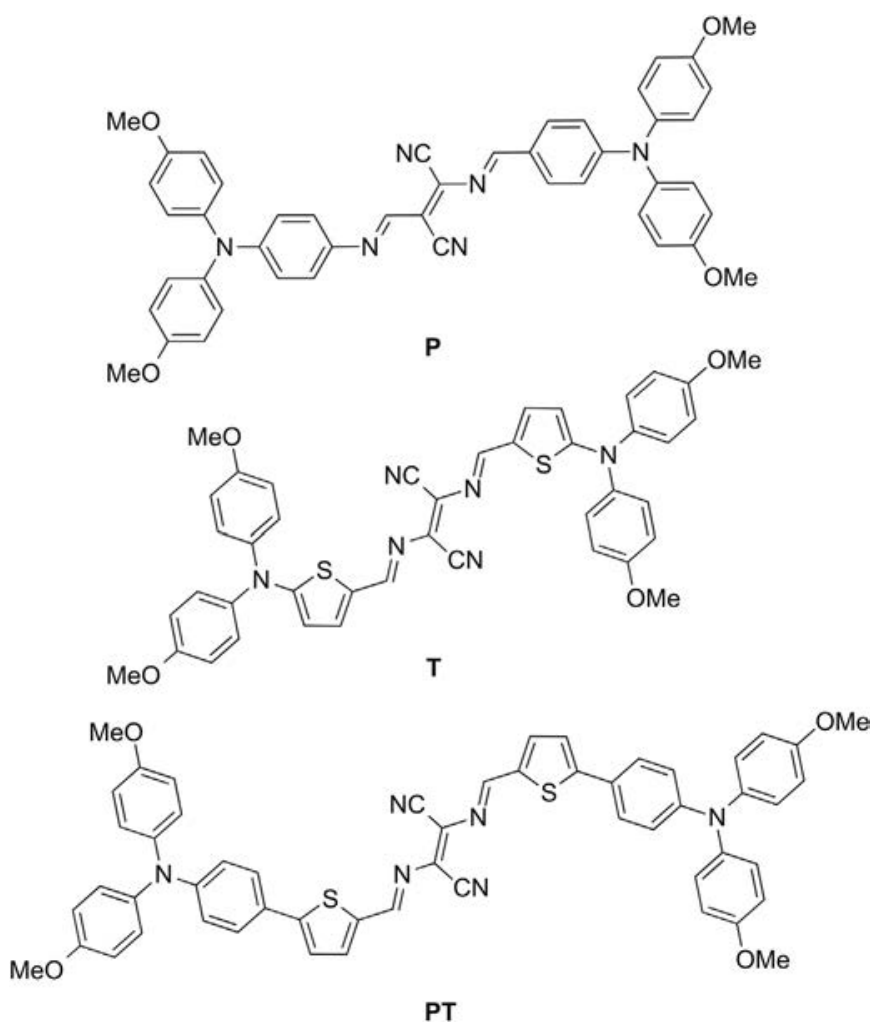

Fig. 1. Structures of the target compounds.

\section{Experimental}

\subsection{General}

Solvents were purified and dried using standard protocols. ${ }^{1} \mathrm{H}$ NMR and ${ }^{13} \mathrm{C}$ NMR spectra were recorded on a Bruker AVANCE DRX 300 spectrometer; chemical shifts are given in ppm (relative to tetramethylsilane) and coupling constants $(J)$ in Hz. MALDI-TOF experiments were carried out on a Bruker Biflex-III with $\mathrm{N}_{2}$ laser (337 nm) as irradiation source with dithranol in $\mathrm{CH}_{2} \mathrm{Cl}_{2}$ as matrix. High resolution mass spectra were recorded under FAB mode on a Jeol JMS 700 spectrometer. UV-visible optical data were recorded with a Perkin-Elmer lambda 950 spectrophotometer. Thermal analyses were performed using a DSC 2010 CE (TA Instruments). For cyclic voltammetry (scan rate $100 \mathrm{mV} \mathrm{s}^{-1}$ ), the electrochemical apparatus consisted of a potentiostat Biologic SP 150 driven by EClab software and of a standard three-electrode cell. As the working and counter electrodes, a platinum foil and a platinum wire were used, respectively, while an SCE electrode was used as a reference.

\subsection{Devices preparation and characterization}

Fullerene $C_{60}(99+\%)$ was purchased from Merck and used as received. The Baytron suspension used to apply smoothing and hole conducting/injecting layers was purchased as "Baytron P PE FL" (HC Stark). All thin film devices were prepared in laboratory conditions. As electrodes, ITO coated glasses $(20 \Omega / \square$, Solem) and evaporated Al films (ca. $150 \mathrm{~nm}$ thickness) were used. The ITO electrodes were cleaned in ultrasonic baths, subjected to an UV-ozone treatment (15 min), and then modified by a spin-casted layer of Baytron (40 nm thickness), which was dried at $115{ }^{\circ} \mathrm{C}$ during $30 \mathrm{~min}$. The Baytron suspension was filtered through a $0.45 \mu \mathrm{m}$ membrane

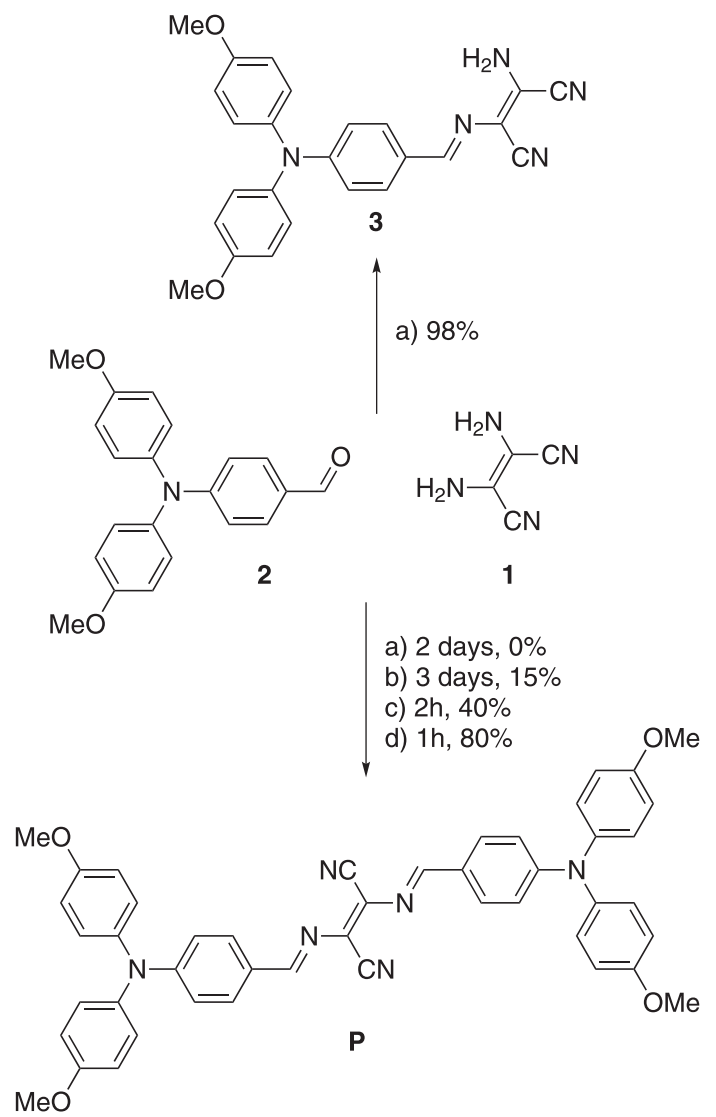

Scheme 1. Synthetic routes to compounds 3 and $\mathbf{P}$. a) ethanol rflx; b) toluene rflx with Dean-Stark; c) toluene, $\mathrm{P}_{2} \mathrm{O}_{5}$, microwave activation, $110^{\circ} \mathrm{C}, 250 \mathrm{~mW}, 6$ bar; d) toluene, TFA, microwave activation, $110{ }^{\circ} \mathrm{C}, 250 \mathrm{~mW}, 6$ bar.

(Minisart RC 15, Sartorius) just prior to casting. The donor layer was spin-casted from chloroform solutions of the compound $\left(5 \mathrm{mg} \mathrm{L}^{-1}\right)$ onto ITO slides initially pre-coated with a $40 \mathrm{~nm}$ PEDOT-PSS layer. Then, a layer of $C 60$ ( $30 \mathrm{~nm}$ ) was deposited by thermal evaporation under high vacuum. A $150 \mathrm{~nm}$ thick layer of Al was finally thermally evaporated through a shadow mask, at a pressure of about $10^{-6}$ mbar. The mask geometry defined a device's area of $0.28 \mathrm{~cm}^{2}$. Each ITO coated glass supports two individual devices. Different "sets" of devices, using the same batch and solution and whereon $\mathrm{Al}$ was evaporated simultaneously, were prepared. For each experiment, a minimum of 16 OSC ( 8 devices containing 2 cells of $0.28 \mathrm{~cm}^{2}$ active area) were characterized. All devices were thermally treated. A sacrificed cell was first heated for $5 \mathrm{~min}$ at $80^{\circ} \mathrm{C}$ after what temperature was increased by increments of $10^{\circ} \mathrm{C}$ until $P C E$ decreases. Then, the other cells were directly heated at the optimized temperature during $5 \mathrm{~min}$.

After preparation, the devices were stored and characterized in an argon glovebox (200B, MBraun). The $J-V$ curves of the devices were recorded in the dark and under illumination using a Keithley 236 source-measure unit and a home-made acquisition program. The light source was an AM 1.5 Solar Constant 575 PV simulator (Steuernagel Lichttecknik, equipped with a metal halogenide lamp). The light intensity was measured by a broad-band power meter (13PEM001, Melles Griot). The devices were illuminated through the ITO electrode side. The efficiency values reported here are not corrected, for possible solar simulator spectral mismatch nor for the reflection/absorbance of the glass/ITO/Baytron coated electrodes. 


\subsection{Synthesis}

\subsubsection{2-amino-3-((E)-(4-(bis(4-methoxyphenyl)amino)}

benzylidene)amino)maleonitrile - 3

The 4-(bis(4-methoxyphenyl)amino)benzaldehyde [10] (0.1 g, $0.3 \mathrm{mmol}$ ) is dissolved in ethanol and 2,3-diaminomaleonitrile ( $35 \mathrm{mg}, 0.32 \mathrm{mmol}$ ) is added. The solution is refluxed for $2 \mathrm{~h}$ and then, the mixture is cooled at room temperature. An orange solid is filtered off, and is washed with water and ethanol to afford the target compound $(0.125 \mathrm{~g}, 98 \%)$. Monocrystals are obtained by slow evaporation of ethyl acetate. M.p.: $167-172{ }^{\circ} \mathrm{C} ;{ }^{1} \mathrm{H} \mathrm{NMR}(300 \mathrm{MHz}$, $\left.\mathrm{CDCl}_{3}\right): 8.27(\mathrm{~s}, 1 \mathrm{H}), 7.58(\mathrm{~d}, 2 \mathrm{H}, J=8.7 \mathrm{~Hz}), 7.12(\mathrm{~d}, 4 \mathrm{H}, J=9 \mathrm{~Hz})$, $6.88(\mathrm{~d}, 4 \mathrm{H}, J=9 \mathrm{~Hz}), 6.84(\mathrm{~d}, 2 \mathrm{H}, J=8.7 \mathrm{~Hz}), 4.95,(\mathrm{~s}, 2 \mathrm{H}), 3.82(\mathrm{~s}$, $6 \mathrm{H}) ;{ }^{13} \mathrm{C} \mathrm{NMR}\left(125 \mathrm{MHz}, \mathrm{CDCl}_{3}\right): 158.5,157.1,152.6,139,130.6,127.8$, $125.7,122.3,117.7,114.9,114.1,112.6,109.7,55.5$; IR (neat): $\nu=2208$, $2229 \mathrm{~cm}^{-1}(\mathrm{C} \equiv \mathrm{N}), 3304,3410(\mathrm{~N}-\mathrm{H})$; X-Ray structure: Triclinic, $\mathrm{P}-1$ (CCDC 1015083, details see below).

\subsubsection{2,3-bis((E)-(4-(bis(4-methoxyphenyl)amino)benzylidene) amino)fumaronitrile $-P$}

Route B: 4-(bis(4-methoxyphenyl)amino)benzaldehyde $(120 \mathrm{mg}, 0.36 \mathrm{mmol})$ and 2,3-diaminomaleonitrile (18 $\mathrm{mg}$, $0.17 \mathrm{mmol})$ are dissolved in benzene $(20 \mathrm{~mL})$ and several drops of piperidine are added. The solution is vigorously stirred for $30 \mathrm{~min}$ and then heated to reflux with a Dean-Stark apparatus during 5 days. The reaction mixture is cooled to room temperature, diluted with $\mathrm{CH}_{2} \mathrm{Cl}_{2}$, and washed with a saturated solution of $\mathrm{NaHCO}_{3}$, water and brine. After removal of solvent the residue is purified by column chromatography on silica gel using methylene chloride as eluent to afford a purple solid (30 $\mathrm{mg}, 24 \%$ ).

Route D: 4-(bis(4-methoxyphenyl)amino)benzaldehyde (90 mg, $0.27 \mathrm{mmol})$ and 2,3-diaminomaleonitrile (14 mg, $0.13 \mathrm{mmol}$ ) are dissolved in toluene $(5 \mathrm{~mL})$ in a $10-\mathrm{mL}$ vial. Then trifluoroacetic acid is added $(30 \mu \mathrm{L})$ and the vial is sealed with a crimp cap and placed in the microwave cavity (CEM Discover). After irradiation at $250 \mathrm{~W}$ $110{ }^{\circ} \mathrm{C}$, (6 bar) during $60 \mathrm{~min}$ and subsequent cooling, the reaction mixture is then diluted with $\mathrm{CH}_{2} \mathrm{Cl}_{2}$, washed with a saturated solution of $\mathrm{NaHCO}_{3}$, water and brine. After removal of solvent, the residue is chromatographed on silica gel using methylene chloride as eluent to afford a purple solid (77 $\mathrm{mg}, 80 \%$ ).

Monocrystals are obtained by slow evaporation of chloroform. M.p.: $174-178{ }^{\circ} \mathrm{C} ; \mathrm{RMN}^{1}{ }^{\mathrm{H}}\left(300 \mathrm{MHz}, \mathrm{CDCl}_{3}\right): 8.56(\mathrm{~s}, 1 \mathrm{H}), 7.74(\mathrm{~d}$, $2 \mathrm{H}, J=8.7 \mathrm{~Hz}$ ), $7.13 \mathrm{ppm}(\mathrm{d}, 4 \mathrm{H}, J=8.7 \mathrm{~Hz}), 6.88 \mathrm{ppm}(\mathrm{m}, 6 \mathrm{H}), 3.82$ (s, 6H); RMN- ${ }^{13} \mathrm{C}\left(125 \mathrm{MHz}, \mathrm{CDCl}_{3}\right): 162.5,157.3,153.3,138.7,131.8$, 130.5, 127.9, 125.8, 117.5, 115, 111.5, 55.5; IR (neat): $\nu=2210 \mathrm{~cm}^{-1}$ $(\mathrm{C} \equiv \mathrm{N})$; Elemental analysis: calculated for $\mathrm{C}_{46} \mathrm{H}_{38} \mathrm{~N}_{6} \mathrm{O}_{4}: \mathrm{C}, 74.78 ; \mathrm{H}$, 5.18; N, 11.31; found: C, 74.72; H, 5.21; N, 11.31; X-Ray structure: Orthorhombic, P 212121 (CCDC 1015081, see below).

\subsubsection{2,3-bis((E)-((5-(bis(4-methoxyphenyl)amino)thiophen-2-yl) methylene)amino) fumaronitrile $-T$}

5-(bis(4-methoxyphenyl)amino)thiophene-2-carbaldehyde [11] ( $70 \mathrm{mg}, 0.21 \mathrm{mmol}$ ) and 2,3-diaminomaleonitrile ( $11 \mathrm{mg}, 0.1 \mathrm{mmol}$ ) are dissolved in toluene $(5 \mathrm{~mL})$ in a $10-\mathrm{mL}$ vial. Then trifluoroacetic

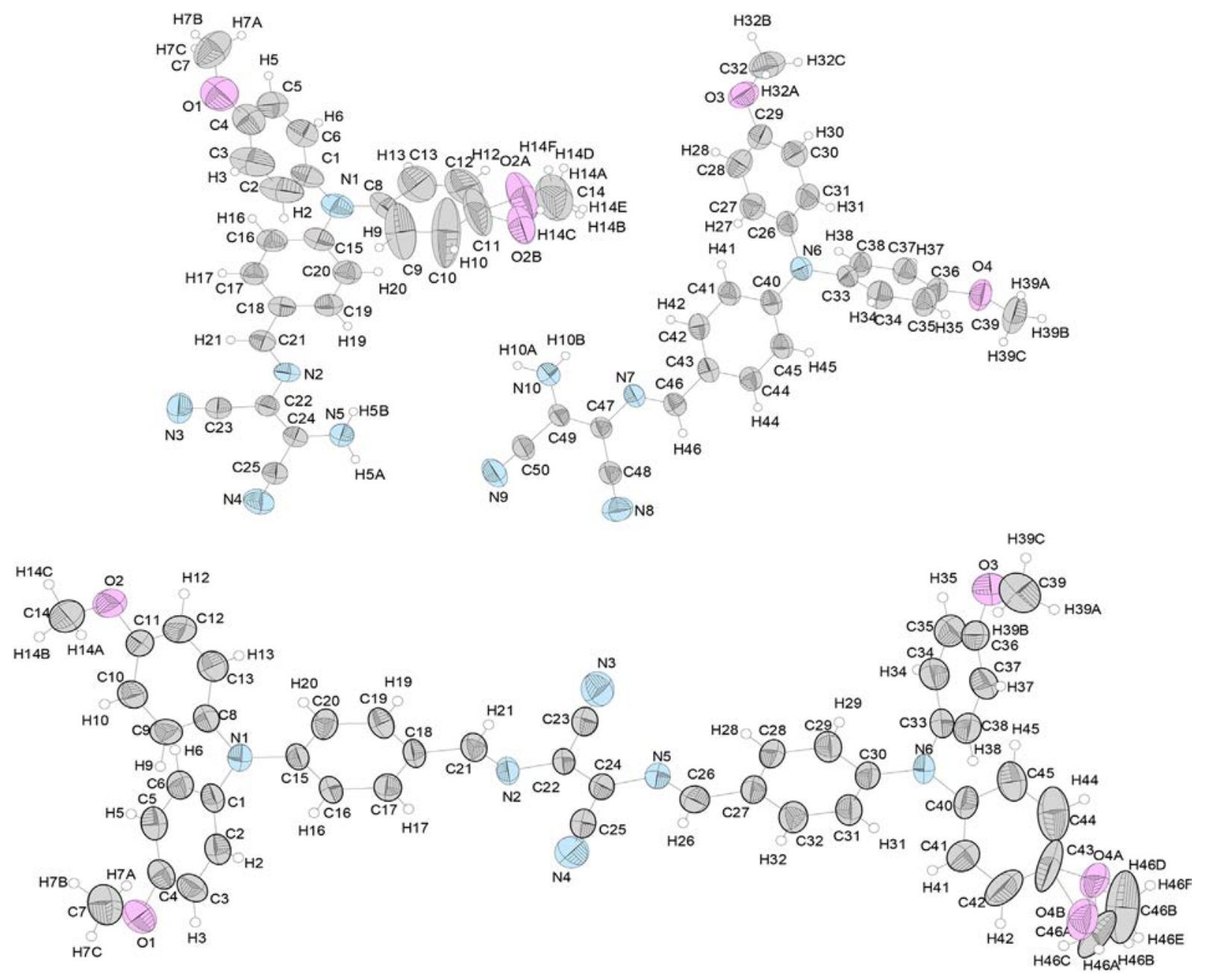

Fig. 2. ORTEP view of $\mathbf{3}$ (top) and $\mathbf{P}$ (bottom). 

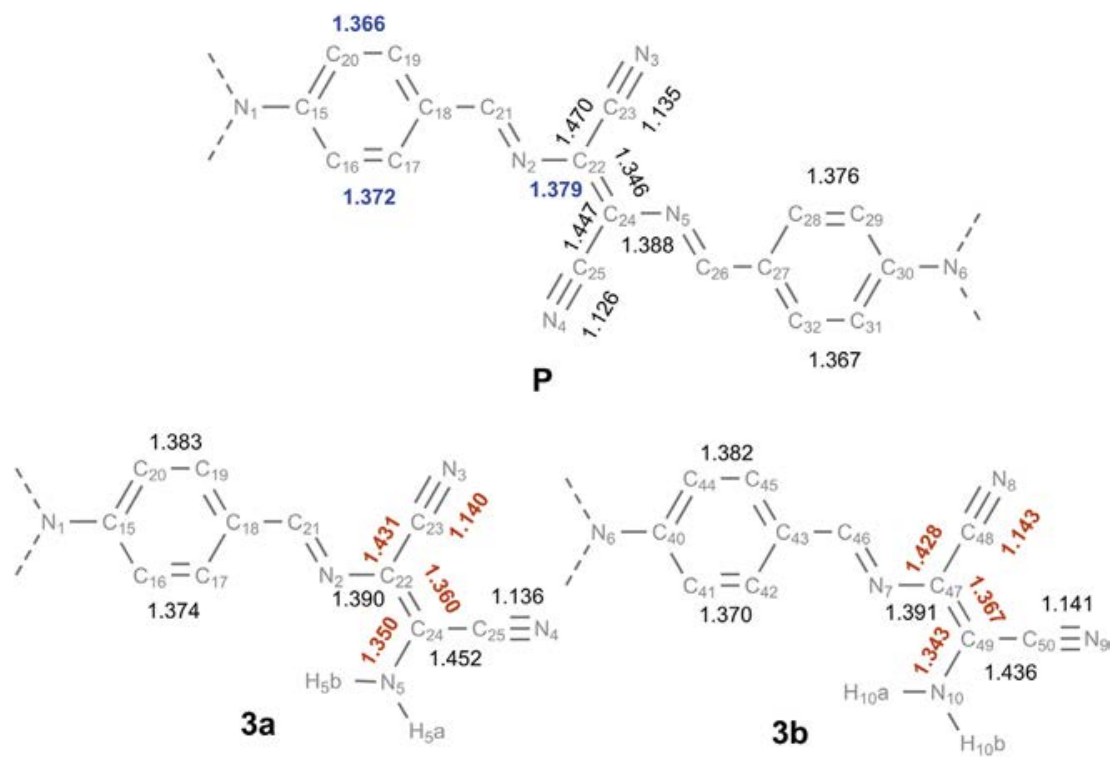

Fig. 3. Selected bond length extracted form X-ray data, top $\mathbf{P}$, bottom compounds 3a and $\mathbf{3 b}$ (detailed X-ray structures in SI).

acid is added $(30 \mu \mathrm{L})$ and the vial is sealed with a crimp cap and placed in the microwave cavity (CEM Discover). After irradiation at $250 \mathrm{~W}, 110{ }^{\circ} \mathrm{C}$, (6 bar) during $60 \mathrm{~min}$ and subsequent cooling, the reaction mixture is then diluted with $\mathrm{CH}_{2} \mathrm{Cl}_{2}$, washed with a saturated solution of $\mathrm{NaHCO}_{3}$, water and brine. After removal of solvent the residue is purified by column chromatography on silica gel using methylene chloride as eluent to afford a blue solid (45 mg, $60 \%$ ). $\mathrm{RMN}-{ }^{1} \mathrm{H}(300 \mathrm{MHz}, \mathrm{CDCl} 3): 8.26(\mathrm{~s}, 1 \mathrm{H}), 7.25$ (d, $1 \mathrm{H}$, $J=4.4 \mathrm{~Hz}$ ), 7.23 (d, $4 \mathrm{H}, J=8.9 \mathrm{~Hz}), 6.90(\mathrm{~d}, 4 \mathrm{H}, J=8.9 \mathrm{~Hz}), 6.17(\mathrm{~d}$, $1 \mathrm{H}, J=4.4 \mathrm{~Hz}), 3.82(\mathrm{~s}, 6 \mathrm{H})$; RMN $-{ }^{13} \mathrm{C}(75 \mathrm{MHz}, \mathrm{CDCl} 3)$ : $165.3,158$, 153.8, 138.8, 128.1, 127.1, 119.5, 115.1, 114.7, 111.9, 111, 55.5. M.p.: 155-159 ${ }^{\circ} \mathrm{C}$; IR (neat): $\nu=2208 \mathrm{~cm}^{-1}(\mathrm{C} \equiv \mathrm{N})$; MS (MALDI-TOF) $\left[\mathrm{M}^{+\bullet}\right]$ :750.9; HRMS (MALDI-TOF) $\left[\mathrm{M}^{+\cdot}\right]$ : Calculated 750.2083, Found 750.2095 (1.6 ppm).

\subsubsection{2,3-bis((E)-((5-(4-(bis(4-methoxyphenyl)amino)phenyl)} thiophen-2-yl)methylene)amino) fumaronitrile $-P T$

5-(4-(bis(4-methoxyphenyl)amino)phenyl)thiophene-2carbaldehyde [12] (90 $\mathrm{mg}, 0.22 \mathrm{mmol})$ and 2,3diaminomaleonitrile (12 $\mathrm{mg}, 0.11 \mathrm{mmol}$ ) are dissolved in toluene $(5 \mathrm{~mL})$ in a $10-\mathrm{mL}$ vial. Then trifluoroacetic acid is added $(30 \mu \mathrm{L})$ and the vial is sealed with a crimp cap and placed in the microwave cavity (CEM Discover). After irradiation at $250 \mathrm{~W}, 110{ }^{\circ} \mathrm{C}$, (6 bar) during $60 \mathrm{~min}$ and subsequent cooling, the reaction mixture is then diluted with $\mathrm{CH}_{2} \mathrm{Cl}_{2}$, washed with a saturated solution of $\mathrm{NaHCO}_{3}$, water and brine. After removal of solvent the residue is purify by column chromatography on silica gel using methylene chloride as eluent to afford a dark-blue solid (67 mg, 68\%). M.p.: $149-153^{\circ} \mathrm{C}$; $\mathrm{RMN}-{ }^{1} \mathrm{H}\left(300 \mathrm{MHz}, \mathrm{CDCl}_{3}+\mathrm{Et}_{3} \mathrm{~N}\right): 8.75(\mathrm{~s}, 1 \mathrm{H}), 7.57(\mathrm{~d}, 1 \mathrm{H}$, $J=4.2 \mathrm{~Hz}), 7.49(\mathrm{~d}, 2 \mathrm{H}, J=8.7 \mathrm{~Hz}), 7.28(\mathrm{~d}, 1 \mathrm{H}, J=4.2 \mathrm{~Hz}), 7.10(\mathrm{~d}$,
$4 \mathrm{H}, J=9 \mathrm{~Hz}), 6.88(\mathrm{~m}, 6 \mathrm{H}), 3.81(\mathrm{~s}, 6 \mathrm{H}) ; \mathrm{RMN}-{ }^{13} \mathrm{C}\left(75 \mathrm{MHz}, \mathrm{CDCl}_{3}\right)$ : 157.6, 156.6, 150.5, 150, 140.3, 139.2, 132.4, 127.3, 127.2, 122.8, 122.5, 118.6, 114.7, 114.5, 113.6, 55.3; IR (neat): $\nu=2209 \mathrm{~cm}^{-1}(\mathrm{C} \equiv \mathrm{N})$; MS (MALDI-TOF) [ $\left.\mathrm{M}^{+\cdot}\right]$ :902.2; HRMS (MALDI-TOF) $\left[\mathrm{M}^{+\cdot}\right]$ : Calculated 902.2704, Found 902.2698 (0.66 ppm).

\section{Results and discussion}

\subsection{Synthesis}

Mono-condensation of commercially available (Z)-2,3diaminomaleonitrile $\mathbf{1}$ with aromatic monoaldehydes can be carried out in refluxing ethanol [13] or, even at room temperature, in water in some cases [14]. When condensation of 4-(bis(4methoxyphenyl)amino)benzaldehyde 2 [10] with 1 is carried out in ethanol (Scheme 1, route a), the product of mono-condensation 3 is quantitatively obtained after a simple crystallization. The analysis of the reaction mixture does not reveal any trace of the biscondensation product (even under longer reaction times). In order to promote the bis-condensation, Chou et al. [15] used catalytic amounts of $\mathrm{H}_{2} \mathrm{SO}_{4}$. Unfortunately, in our case, this procedure leads to the complete decomposition of the compounds. Refluxing in benzene in the presence of a catalytic amount of piperidine [16], gave the target compound $\mathbf{P}$ only as traces. Although TLC monitoring of the reaction revealed a quasi-immediate formation of compound $\mathbf{3}$, the thermal instability of $\mathbf{P}$ appeared as a serious drawback for its formation in decent yield. Water removal with a Dean-Stark improved the yield of $\mathbf{P}$ to $15 \%$ but the presence of a large amount of $\mathbf{3}$ in the reaction mixture complicated the purification procedure. Application of the same experimental conditions

Table 1

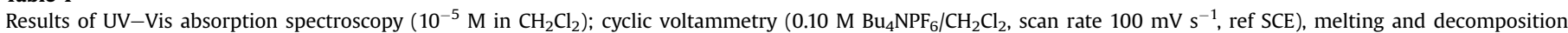
temperatures data for compounds $\mathbf{P}, \mathbf{T}$ and $\mathbf{P T}$.

\begin{tabular}{|c|c|c|c|c|c|c|c|c|c|c|c|}
\hline Cpnd & $\lambda(\mathrm{nm})$ & $\varepsilon(\mathrm{L} / \mathrm{mol} / \mathrm{cm})$ & $\operatorname{Epa}^{1}(\mathrm{~V})$ & $\operatorname{Epa}^{2}(\mathrm{~V})$ & Epc (V) & HOMO $(\mathrm{eV})$ & LUMO (eV) & $\Delta E^{\text {theo }}(\mathrm{eV})$ & $E_{g}^{\text {mat }}(\mathrm{eV})$ & $\operatorname{Tf}\left({ }^{\circ} \mathrm{C}\right)$ & $\operatorname{Td}\left({ }^{\circ} \mathrm{C}\right)$ \\
\hline $\mathbf{P}$ & 559 & 65,000 & 0.78 & 0.88 & $-1.19^{a}$ & -4.74 & -2.43 & 2.31 & 1.82 & 176 & 203 \\
\hline $\mathbf{T}$ & 620 & 28,000 & 0.62 & 0.74 & $-1.28^{a}$ & -4.52 & -2.29 & 2.23 & 1.61 & 151 & 208 \\
\hline PT & 623 & 52,500 & $0.72^{\mathrm{b}}$ & $1.37^{\mathrm{a}}$ & $-1.0^{\mathrm{a}}$ & -4.68 & -2.69 & 1.99 & 1.70 & 157 & 224 \\
\hline
\end{tabular}

a Irreversible process.

b Coalescence of two one-electron processes. 


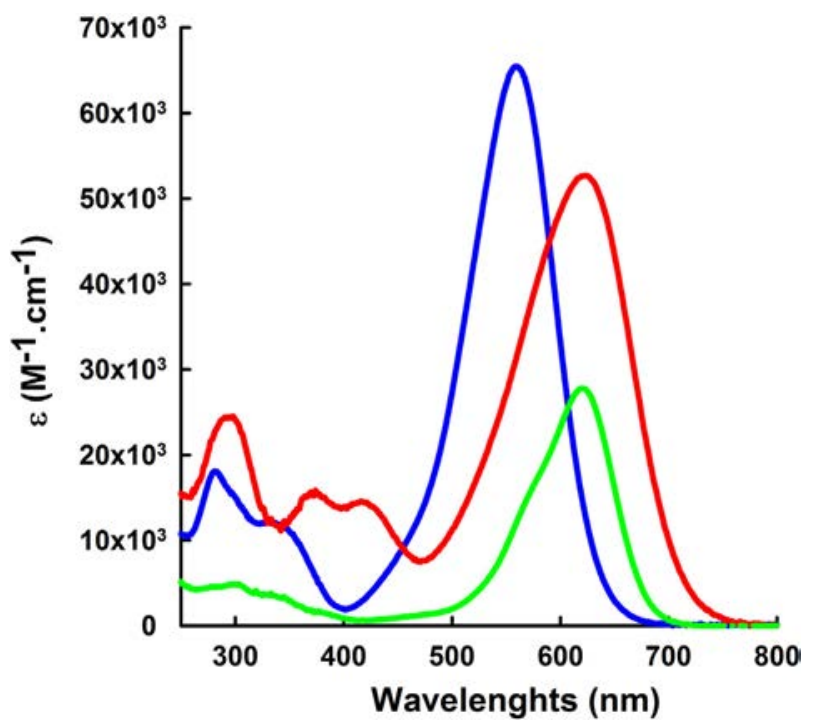

Fig. 4. UV-Vis Absorption spectra of the target compounds in $\mathrm{CH}_{2} \mathrm{Cl}_{2}$. $\mathbf{P}$ (blue), $\mathbf{T}$ (green) and PT (red). (For interpretation of the references to colour in this figure legend, the reader is referred to the web version of this article.)

to 5-(bis(4-methoxyphenyl)amino)thiophene-2-carbaldehyde 4 [11] and 5-(4-(bis(4-methoxyphenyl)amino)phenyl) thiophene-2carbaldehyde 5 [12] led to compounds $\mathbf{T}$ and $\mathbf{P T}$ in 16 and $11 \%$ yield respectively.

The difficulty to achieve the second condensation reaction prompted us to study the crystallographic structure of compounds 3 and $\mathbf{P}$. After slow evaporation from chloroform solution,
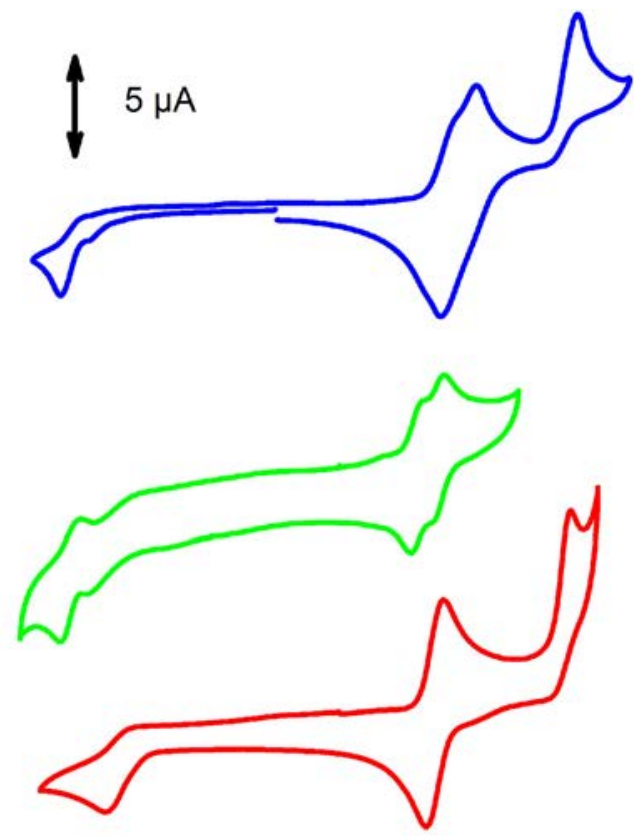

$-1$

0 1

\section{$\mathrm{E}(\mathrm{V} / \mathrm{SCE})$}

Fig. 5. $\mathrm{CV}$ traces of $\mathbf{P}$ (top), $\mathbf{T}$ (middle) and $\mathbf{P T}$ (bottom) in $0.10 \mathrm{M} \mathrm{TBAPF} / \mathrm{CH}_{2} \mathrm{Cl}_{2}$ scan rate $100 \mathrm{mV} / \mathrm{s}$ compound $\mathbf{P}$ crystallizes in an orthorhombic $\mathrm{P} 2{ }_{1} 2_{1} 2_{1}$ space group (Fig. 2, bottom). Evaporation from an ethyl acetate solution leads to crystallisation in a P-1 triclinic space group with two independent molecules $\mathbf{3 a}$ and $\mathbf{3 b}$ by unit (Fig. 2, top). The crystallographic structures of the compounds show the typical geometry of TPA (for more details see ESI). For compound 3, the double bond linking the two cyano groups presents the $Z$ configuration of the starting 2,3diaminomaleonitrile. In contrast for compound $\mathbf{P}$, this bond is isomerized into an $E$ configuration in agreement with previous $\mathrm{X}$-ray data of parent systems.

This $Z / E$ isomerization from $\mathbf{3}$ to $\mathbf{P}$ could contribute to explain the low yield of the second condensation reaction. The main conjugated system of compound $\mathbf{P}$ presents a strong quinodimethanic character from the lateral triarylated nitrogen atom to the central cyano group. For example, the lengths of C19-C20 1.366 $\AA$ and C16-C17 $1.372 \AA$ in the aromatic spacer and the C22-N2 central single bond (1.379 $\AA$ ) appear particularly short (Fig. 3). For compound 3, this quinodimethanic character is also present but less marked due to the presence of an internal charge transfer between the lateral amino and central cyano groups.

Thus, compared to those of $\mathbf{P}$, bond lengths of $\mathbf{3}$ (in red on Fig. 3) show significant lengthening for double and triple bonds and notable shortening for single ones. This observation suggests the existence of a strong ICT between nitrogen atoms N5 and N10 and the $\mathrm{C} 23-\mathrm{N} 3$ and C48-N8 cyano groups respectively. This assumption is corroborated by the $\mathrm{sp} 2$ geometry of N5 and N10 shown by the localization (determined from their electronic densities) of hydrogen atoms H5a-b and H10a-b in the same plane as the conjugated system. This observation may explain the lack of reactivity of compound $\mathbf{3}$ in which the terminal doublet on nitrogen looses a part of its nucleophile properties.

Whereas the low nucleophily of the nitrogen is probably a limiting factor, the required $Z / E$ isomerization of the central double bond represents a major obstacle to the efficiency of the biscondensation. This isomerization must occur during the second condensation step since the $Z$ isomer of $\mathbf{P}$ has never been observed. Thus, in the next experiment, the catalytic amount of basic piperidine was replaced by dehydrating and acidic phosphorus oxide. While $\mathrm{P}_{2} \mathrm{O}_{5}$ does not improve the yield of condensation under atmospheric conditions, its association with microwave activation [17] strongly accelerates the reaction allowing the formation of $\mathbf{P}$ in $40 \%$ yield (route c, Scheme 1). After several attempts with other acids associated with microwave activation, it was found that small amounts of trifluoroacetic acid provides the best results (route $d$, Scheme 1). Under these conditions, 2 eq. of aldehyde 2 with 1 eq. of 1 gives compound $\mathbf{P}$ in $\mathrm{ca} 80 \%$ yield. On the other hand, a similar yield of $\mathbf{P}$ is obtained by reaction of stoichiometric quantities of $\mathbf{3}$

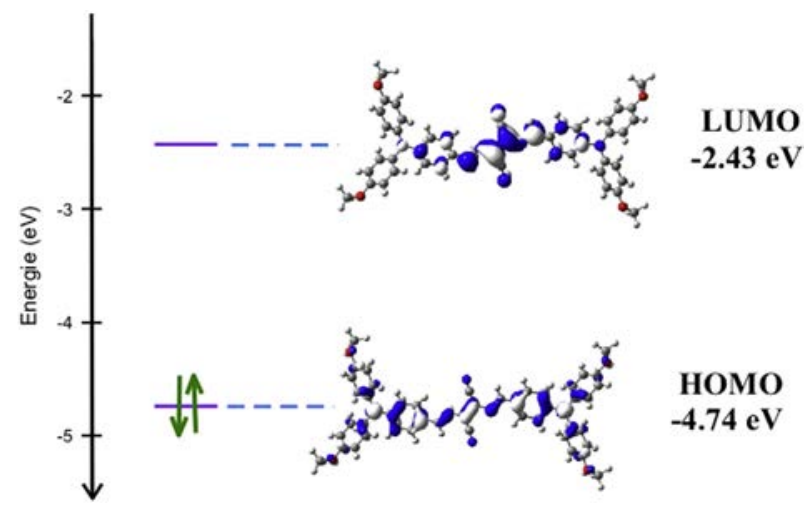

Fig. 6. HOMO and LUMO energetic levels for $\mathbf{P}$. 
Table 2

Photovoltaic characteristics of OSC before and ${ }^{\mathrm{a}}$ after 5 min annealing at $120^{\circ}$, after 5 min annealing at $110^{\circ}$.

\begin{tabular}{lllll}
\hline Cpnd & $V_{\text {oc }}(\mathrm{V})$ & $J_{\text {sc }}\left(\mathrm{mA} \mathrm{cm}^{-2}\right)$ & FF $(\%)$ & PCE (\%) \\
\hline $\mathbf{P}$ & 0.73 & 2.49 & 35 & 0.70 \\
$\mathbf{P}^{\mathrm{a}}$ & 0.84 & 3.65 & 35 & 1.18 \\
$\mathbf{T}$ & 0.47 & 2.20 & 47 & 0.53 \\
$\mathbf{T}^{\mathrm{b}}$ & 0.52 & 4.28 & 36 & 0.89 \\
\hline
\end{tabular}

and 2. Application of these optimized conditions to aldehydes 4 and $\mathbf{5}$ leads in every case to a large improvement of the reaction yield and the target compounds T and PT are obtained in 68 and 60\% yield respectively.

\subsection{Electronic properties of the donors}

Table 1 lists the results of UV-Vis absorption spectroscopy and cyclic voltammetry for the three target compounds. The absorption spectrum of all compounds presents a first series of bands between 280 and $420 \mathrm{~nm}$ followed by an intense band in the $450-750 \mathrm{~nm}$ region assigned to an internal charge-transfer (Fig. 4). The replacement of a phenyl ring by a thienyl unit from $\mathbf{P}$ to $\mathbf{T}$ leads to a large red shift $(61 \mathrm{~nm})$ of the absorption maximum $\lambda_{\max }$, and hence to a decrease of the optical bandgap. However, the extension of the conjugated system from $\mathbf{T}$ to PT produces only a small red shift of $\lambda_{\max }(3 \mathrm{~nm})$.

The cyclic voltammogram of the three compounds presents two one-electron reversible oxidation processes followed by an irreversible wave (Table 1, Fig. 5). As expected the potential of the two first oxidation processes decreases from $\mathbf{P}$ to $\mathbf{T}$ due to the lower aromaticity of thiophene. The extension of the conjugation length in PT leads to the coalescence of the two-one-electron processes at a less positive potential. For all compounds, the CV present an irreversible reduction peak in the -1.00 to $-1.30 \mathrm{~V}$ region.

$A b$ initio theoretical calculations were performed using Gaussian 09 (DFT-B3LYP/6-31g (d, p)). In agreement with the crystal structure of $\mathbf{P}$, the optimized geometries of compounds all exhibit shortening of single bonds and lengthening of double bonds of the conjugated system from the lateral triarylated nitrogen atom to the central cyano group, characteristic of internal charge transfer.

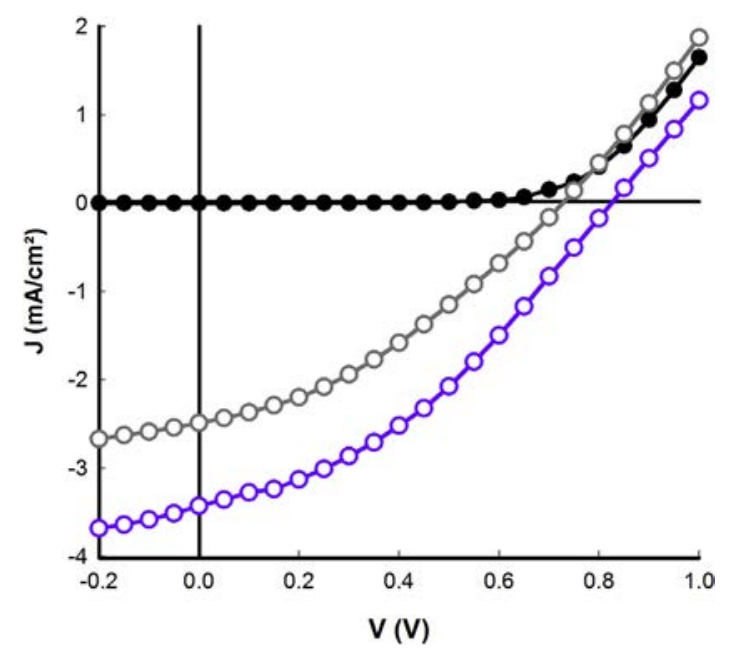

Fig. 7. Current density vs voltage curve for the bilayer planar heterojunction cell $\mathbf{P} / \mathbf{C} 60$ in obscurity (black) and under white illumination at a power of $90 \mathrm{~mW} \mathrm{~cm} \mathrm{c}^{-2}$ before (grey) and after (violet) annealing. (For interpretation of the references to colour in this figure legend, the reader is referred to the web version of this article.)
Whereas compounds $\mathbf{P}$ and $\mathbf{T}$ appear nearly planar, steric interactions between phenyl and thiophene rings of PT produces a dihedral angle of $19^{\circ}$ (see ESI). This twist angle which limits electron delocalization could explain the very small red shift observed between $\mathbf{T}$ and $\mathbf{P T}$ as well as the coalescence of oxidation processes.

The HOMO is delocalized on the whole molecule with smaller coefficients on the central acceptor part while the LUMO is essentially localized on the electron-withdrawing part and vicinal spacer (Fig. 6 and ESI). The calculated HOMO and LUMO levels are consistent with optical and electrochemical results.

\subsection{Evaluation of the new donor molecules in organic solar cells}

The thermal stabilities of the target compounds were investigated by differential scanning calorimetry and thermogravimetry. They all exhibit reasonable thermal stabilities with melting and decomposition points up to $150{ }^{\circ} \mathrm{C}$ and $200{ }^{\circ} \mathrm{C}$ respectively (Table 1). Compounds $\mathbf{P}, \mathbf{T}$ and $\mathbf{P T}$ have been evaluated as donor material in PHJ solar cells ITO/PEDOT-PSS/donor/ $/ \mathrm{C}_{60} / \mathrm{Al}$ (see SI). The open-circuit voltage $\left(V_{\mathrm{oc}}\right)$, short-circuit current densities $\left(J_{\mathrm{sc}}\right)$, fill factor (FF) and power conversion efficiencies (PCE) of cells of $0.28 \mathrm{~cm}^{2}$ active area were determined under AM 1.5 simulation solar illumination (Table 2).

Compound PT did not lead to devices of quality sufficient for evaluation. As-fabricated devices obtained from $\mathbf{P}$ and $\mathbf{T}$ respectively gave PCE of 0.70 and $0.53 \%$. Both devices show similar $J_{\text {sc }}$ associated with $V_{\text {oc }}$ related on relative oxidation potentials. Thus, compound $\mathbf{P}$, which presents a 1 st oxidation potential $160 \mathrm{mV}$ anodically shifted relatively to $\mathbf{T}$, leads to a higher $V_{\text {oc }}$ of $0.73 \mathrm{~V}$. In each case thermal annealing improves the photovoltaic performances due to a slight increase of $V_{\mathrm{oc}}$ and $J_{\mathrm{sc}}$. Thus, PCE of the device based on $\mathbf{T}$ increases from of 0.53 to $0.89 \%$ upon thermal treatment. The highest value of $1.18 \%$ was obtained with $\mathbf{P}$ after annealing at $120^{\circ} \mathrm{C}$, with $V_{\text {oc }}$ of $0.84 \mathrm{~V}$ and a $J_{\text {sc }}$ of $3.65 \mathrm{~mA} \mathrm{~cm}{ }^{-2}$ (Fig. 7).

\section{Conclusion}

To summarize, three new D-A-D molecular systems based on a central diiminofumaronitrile acceptor group substituted by two diarylamine side blocks have been synthesized.

The optimization of the reaction by association of microwave activation and trifluoroacetic acidic catalysis improves the reproducibility of the synthesis and increases the yield from 10-15 to $65-80 \%$. Preliminary results obtained on bilayer heterojunction solar cells gave efficiencies higher than $1.0 \%$ which suggests that the diiminomaleonitrile $\mathbf{1}$ block may represent an interesting synthon for the synthesis of functional molecular or polymeric conjugated systems for several kind of applications including OSC.

\section{Acknowledgements}

Victorien Jeux Thanks the French minister of research for financial support. Clément Dalinot thanks the University of Angers for granting. Authors thank the Johnson Matthey Company for their generous providing of palladium salts (necessary for the syntheses of starting aldehydes).

\section{Appendix A. Supplementary data}

Supplementary data related to this article can be found at http:// dx.doi.org/10.1016/j.dyepig.2014.09.012. 


\section{References}

[1] Roncali J, Blanchard P, Leriche P. Molecular materials for organic photovoltaics: small is beautiful. Adv Mater 2014;26:3821-38;

Lin Y, Li Y, Zhan X. Small molecule semiconductors for high-efficiency organic photovoltaics. Chem Soc Rev 2012;41:4245-72.

[2] Walker B, Tamayo AB, Dang XD, Zalar P, Seo JH, Garcia A, et al. Nanoscale phase separation and high photovoltazic efficiency in solution-processed small molecule bulk heterojunction solar cells. Adv Funct Mater 2009;19: 3063-9;

Ripaud E, Demeter D, Rousseau T, Boucard-Cétol E, Allain M, Po R, et al Structure-properties relationships in conjugated molecules based on diketopyrrolopyrrole for organic photovoltaics. Dyes Pigments 2012;95:126-33; Kim Y, Song CE, Cho A, Kim J, Eom Y, Ahn J, et al. Synthesis of diketopyrrolopyrrole (DPP)-based small molecule donors containing thiophene or furan for photovoltaic application. Mat Chem Phys 2014;143:825-9;

Mei J, Graham KR, Stalder R, Reynolds JR. Synthesis of isoindigo-based oligothiophenes for molecular bulk heterojunction solar cells. Org Lett 2010;12: 660-3;

Yassin A, Leriche P, Allain M, Roncali J. Donor-acceptor-donor (D-A-D) molecules based on isoindigo as active material for organic solar cells. New ] Chem 2013:37:502-7;

Rousseau T, Cravino A, Bura T, Ulrich G, Ziessel R, Roncali J. Bodipy derivatives as donor materials for bulk heterojunction solar cells. Chem Commun 2009: 1673-5;

Rousseau T, Cravino A, Ripaud E, Leriche P, Rihn S, De Nicola A, et al. A tailored hybrid bodipy-oligothiophene donor for momecular bulk heterojunction solar cells with imporves performaznces. Chem Commun 2010:5082-4.

[3] Sun Y, Welch GC, Leong WL, Takacs CJ, Bazan G, Heeger AJ. Solution-processed small-molecule solar cells with 6.7\% efficiency. Nat Mater 2011;11:44-8; Coughlin JE, Henson ZB, Welch GC, Bazan G. Design and synthesis of molecular donors for solution-processed high-efficiency organic solar cells. Acc Chem Res 2014;47:257-70;

Zhou J, Zuo Y, Wan X, Long G, Zhang Q, Ni W, et al. Solution-processed and high-performance organic solar cells using small molecules with a benzodithiophene unit. I Am Chem Soc 2013;135:8484-7;

Chen Y, Wan X, Long G. High performance photovoltaic applications using solution-processed small molecules. Acc Chem Res 2013;46:2645-55;

Shen S, Jiang P, He C, Zhang J, Shen P, Zhang Y, et al. Solution-processable organic molecule photovoltaic materials with bithienyl-benzodithiophene central unit and indenedione end groups. Chem Mater 2013;25:2274-81.

[4] Jorgensen M, Carlé JE, Sondergaard RR, Lauritzen M, Dagnaes-Hansen NA Byskov SL, et al. The state of organic solar cells-a meta analysis. Sol En Mater Sol Cells 2013;119:84-93;

Po R, Bernardi A, Calabrese A, Carbonera C, Corso G, Pellegrino A. The role of buffer layers in polymer solar cells. Energy Environ Sci 2014;4:285-310;

Krebs FC, Jorgensen M. Polymer and organic solar cells viewed as thin film technologies: what it will take for them to become a success outside academia. En Mater Sol Cells 2013;119:73-6;

Anctil A, Babbitt CW, Raffaelle RP, Landi BJ. Cumulative energy demand for small molecule and polymer photovoltaics. Prog Photovolt Res Appl 2013;21: $1541-54$.

[5] Leliege A, Blanchard P, Rousseau T, Roncali J. Triphenylamaine/tetracyanobutadiene-based DAD pi-conjugated systems as molecular donors for organic solar cells. Org Lett 2011;12:3098-101.
[6] Moussallem C, Allain M, Gohier F, Frère P. Synthesis, electronic properties and packing modes of conjugated systems based on 2,5-di(cyanovinyl)furan or thiophene and imino-perfluorophenyl moieties. New J Chem 2013;37: 409-15;

Moussalem C, Segut O, Gohier F, Allain M, Frere P. Facile access via Green procedures to a material with the benzodifuran moiety for organic photovoltaics. Sus Chem Eng 2014;2(4):1043-8;

Demeter D, Mohamed S, Diac A, Grosu I, Roncali J. Small molecular donors for organic solar cells obtained by simple and clean synthesis. ChemSusChem 2014;7(4):1046-50.

[7] Lu Y, Hasegawa F, Goto T, Ohkuma S, Fukuhara S, Kawazu Y, et al. Highly sensitive two-photon chromophores applied to three-dimensional lithographic microfabrication: design, synthesis and characterization towards twophoton absorption cross section. J Mater Chem 2004;4:75-80;

Shirai K, Matsuoka M, Fukunishi K. New syntheses and solid state fluorescence of azomethine dyes derived from diaminomaleonitrile and 2,5-diamino-3,6dicyanopyrazine. Dyes Pigments 2000;47:107-15.

[8] Kinashi K, Lee KP, Matsumoto S, Ishida K, Ueda Y. Alkyl substituent effects on J- or H-aggregate formation of bisazomethine dyes. Dyes Pigments 2012;92: 783-8;

Kim BS, Kashibuchi D, Son YA, Kim SH, Matsumoto S. Effect of phenyl ring substitution on J-aggregate formation ability of novel bisazomethine dyes in vapour-deposited films. Dyes Pigments 2011;90:56-64;

Tanaka T, Matsumoto S, Kobayashi T, Soatoh M, Aoyama TJ. Highly oriented Jaggregates of bisazomethine dye on aligned poly(tetrafluoroethylene) surfaces. Phys Chem C 2011;115:19598-605.

[9] Hosokai T, Aoyama T, Kobayashi T, Nakao A, Matsumoto S. Photovoltaic properties of bisazomethine dye thin films. Chem Phys Lett 2010;487:77-80.

[10] He Z, Kan CW, Ho CL, Wong WY, Chui CH, Tong KL, et al. Light-emitting dyes derived from bifunctional chromophores of diarylamine and oxadiazole: synthesis, crystal structure, photophysics and electroluminescence. Dyes Pigments 2011;88:333-43.

[11] Davies JA, Elangovan A, Sullivan PA, Olbricht BC, Bale DH, Ewy TR, et al. Rational enhancement of second-order nonlinearity: bis-(4-methoxyphenyl) hetero-aryl-amino donor-based chromophores: design, synthesis, and electrooptic activity. J Am Chem Soc 2008;130:10565-75.

12] Yu OY, Liao JY, Zhou SM, Shen Y, Liu JM, Kuang DB, et al. Effect of hydrocarbon chain length of disubstituted triphenyl-amine-based organic dyes on dyesensitized solar cells. J Phys Chem C 2011;115:22002-8.

[13] Robertson PS, Vaughan J. Derivatives of the hydrogen cyanide tetramer: structure and chemistry. I Am Chem Soc 1958:80:2691-3; Nesterov VV, Antipin MY, Nesterov VN, Moore CE, Cardelino BH Timofeeva TV. Thermally stable heterocyclic imines as new potential nonlinear optical materials. J Phys Chem B 2004;108:8531-9.

[14] Rivera A, Rios-Motta J, Leon F. Revisiting the reaction between diaminomaleonitrile and aromatic aldehydes: a green chemistry approach. Molecules 2006;11:858-66.

[15] Lin CW, Chou PT, Liao YH, Lin YC, Chen CT, Chen YC, et al Photoisomerization of a maleonitrile-type Salen Schiff base and its application in fine-tuning infinite coordination polymers. Chem Eur J 2010;16:3770-82.

[16] Kim SH, Yoon SH, Kim SH, Han EM. Red electroluminescent azomethine dyes derived from diaminomaleonitrile. Dyes Pigments 2005;64:45-8.

[17] Experiments were conducted with a CEM « Discover» machine 